Кравчук Неля Павлівна кандидат педагогічних наук, доцент кафедри психології та педагогіки розвитку дитини, Уманський державний педагогічний університет імені Павла Тичини, вул. Садова, 28, м. Умань, 20300, тел.: (4744) 3-45-82, https://orcid.org/0000-0002-9420-4375

\title{
ТЕОРЕТИКО-МЕТОДОЛОГІЧНІ АСПЕКТИ РОЗВИТКУ ТВОРЧОГО ПОТЕНЦІАУ ОБДАРОВАНИХ ДОШКІЛЬНИКІВ У ЗАКЛАДАХ ДОШКІЛЬНОЇ ОСВІТИ
}

Анотація. У статті окреслено теоретико-методологічні аспекти розвитку творчого потенціалу обдарованих дошкільників у закладах дошкільної освіти. Досліджено дві категорії понять: «обдарованість» та «творчий потенціал».

Актуальність матеріалу, викладеного у статті, обумовлена тим, що обдаровані діти потребують особливого виховання та спеціальних умов для розвитку їх творчого потенціалу. Простежено, що обдарованість визначається за допомогою вимірювання інтелектуальних параметрів або феноменологічних проявів.

У статті розглядаються різні погляди щодо проблеми дитячої обдарованості зарубіжних та вітчизняних науковців (Г. Альтштулер, О. Кульчицька, О. Матюшкін, О. Проценко, А. Савенков та ін.). Проблему розвитку творчого потенціалу порушено в наукових розвідках О. Дьяченко, Є. Ільїна, А. Лукановської, В. Маслової, Т. Піроженко та ін.

Автори вважають, що обдарована дитина - це особистість, яка вирізняється яскравими, іноді видатними досягненнями у тій чи іншій сфері діяльності, яка є улюбленою для неї, а творчий потенціал - це особистісна характеристика, індивідуальний потенціал для досягнення високих результатів в одній або декількох сферах творчої діяльності (зображувальна, конструктивна, художньо-мовленнєва, театралізована та ін.). Тому, на думку автора, раннє виявлення, навчання і виховання обдарованих дітей - одне 3 головних завдань удосконалення сучасної системи освіти, яке передбачає створення розвивального середовища в умовах закладу дошкільної освіти.

Проаналізовано стандартизовані методики дослідження творчого потенціалу обдарованих дітей, а також вправи та ігри для розвитку творчих здібностей, які використовуються у роботі з дітьми у закладах дошкільної освіти.

Ключові слова: обдарованість, обдарована дитина, творчий потенціал, творчі здібності, креативність, інтелект. 
Kravchuk Nelia Pavlivna Candidate of Pedagogic Sciences (Ph.D.), Associate Professor of the Department of Psychology and Pedagogy of Child Development Pavlo Tychyna Uman State Pedagogical University, Sadova St., 28, Uman, 20300, tel.: (4744) 3-45-82, https://orcid.org/0000-0002-9420-4375

\section{THEORETICAL AND METHODOLOGICAL ASPECTS OF THE DEVELOPMENT OF THE CREATIVE POTENTIAL OF GIFTED PRESCHOOL CHILDREN IN PRESCHOOL EDUCATION INSTITUTIONS}

Abstract. The article outlines the theoretical and methodological aspects of the development of creative potential of gifted preschoolers in preschool institutions. Two categories of concepts have been studied: «giftedness» and «creative potential».

The relevance of the material presented in the article is due to the fact that gifted children need special education and special conditions for the development of their creative potential. It has been observed that giftedness is determined by measuring intellectual parameters or phenomenological manifestations.

The article considers different views on the problem of children's talents of foreign and domestic scientists (G. Altshtuler, O. Kulchytska, O. Matyushkin, O. Protsenko, A. Savenkov, etc.). The problem of the development of creative potential was raised in the scientific research of O. Dyachenko, E. Ilyin, A. Lukanovska, V. Maslova, T. Pirozhenko and others.

The authors believe that a gifted child is a person who has bright, sometimes outstanding achievements in a field of activity that is his favorite, and creative potential is a personal characteristic, individual potential to achieve high results in one or more areas of creative activities (pictorial, constructive, artistic and speech, theatrical, etc.). Therefore, according to the author, early detection, education and upbringing of gifted children is one of the main tasks of improving the modern education system, which involves creating a developmental environment in preschool education.

The standardized methods of research of creative potential of gifted children, and also exercises and games for development of creative abilities which are used in work with children in preschool educational institutions are analyzed.

Keywords: giftedness, gifted child, creative potential, creative abilities, creativity, intellect.

Постановка проблеми. Реформаційні процеси, що ініціюють зміни в системі дошкільної освіти, в освітньому просторі в Україні, торкнулися і системи дошкільної освіти, яка стає більш значущою частиною соціальних перетворень, зокрема, пошуку шляхів і засобів раннього виявлення унікальної своєрідності кожної дитини, iï творчої обдарованості.

Вищезазначене актуалізувало важливість виявлення i розвитку обдарованих дітей та розвитку їх творчого потенціалу, що стає одним із 
пріоритетних завдань дошкільної освіти та підтверджує необхідність вирішення означеної проблеми основними документами в галузі освіти України. Зокрема, у Законі України: «Про дошкільну освіту», «Базовому компоненті дошкільної освіти» та інших документах, в яких розвиток творчих здібностей розглядається першочерговим завданням на найближчі десятиліття.

Аналіз останніх досліджень і публікацій щзодо проблеми обдарованості особистості розглядається в працях: О. Антонової, I. Аверіної, Д. Богоявленської, Л. Венгера, Дж. Гілфорда, Ю. Гільбуха, . Карабаєвої, О. Кульчицької, Н. Лейтеса, О. Леонтьєва, С. Максименка, О. Матюшкіна, В. Моляко, О. Музики, С. Платонової, В. Шадрікова, В. Юркевич й ін.

Проблему розвитку творчого потенціалу порушено в наукових розвідках В. Давидова, О. Дьяченко, Д. Ельконіна, Є. Ільїна, В. Кудрявцева, А. Лукановської, В. Маслової, О. Поддьякова, Т. Піроженко та ін.

На думку психологів, без відповідної підтримки, діти не можуть досягти того високого рівня, на який вони потенційно здатні, тому потрібні спеціальна допомога та керівництво з боку педагогів і батьків у розвитку обдарованої особистості - зокрема, розвитку їі творчого потенціалу.

Мета статті - дослідження теоретико-методологічних аспектів розвитку творчого потенціалу обдарованих дошкільників у закладах дошкільної освіти.

Виклад основного матеріалу. Вивчення дитячої обдарованості як психолого-педагогічного явища актуалізовано освітньою практикою. Базовий компонент дошкільної освіти в Україні передбачає перехід до креативних освітніх технологій навчання дошкільників, відповідно до їхніх нахилів та здібностей. Документ спрямовує педагогів підтримувати прояви у дітей ініціативності, креативності, самостійності, а також дбати про сприятливі для цього умови в закладах дошкільної освіти.

У межах нашого дослідження розглядаємо дві категорії понять: «обдарованість» та «творчий потенціал», кожна 3 яких включає дотичні поняття: «обдаровані діти», «дитяча обдарованість», «творча особистість», «креативність» тощо.

Оскільки обдарованість у дитячому віці можна розглядати як потенціал психологічного розвитку стосовно наступних етапів життєвого шляху особистості, важливо враховувати складність самого поняття обдарованості.

Передусім 3'ясуємо сутність поняття «обдарованість». Акцентуємо увагу, що воно $є$ похідним від слова «дар» та розглядається як результат певного дару, даного людині Природою. 3 цього погляду, будь-яка дитина може стати обдарованою за сприятливих обставин. Підтверджує таку думку дослідник Н. Лейтес, який вважає, що потенційно обдарованими є 93-95 \% загальної кількості обдарованих людей, тобто усі діти обдаровані від народження багатьма талантами і здібностями [1, с. 2].

Відтак, вважаємо, що із задатками обдарованості, здатністю до ефективної плідної діяльності народжується кожна психічно нормальна людина, яка має 


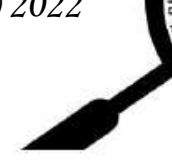

потенційні здібності у тій чи іншій сфері діяльності. А ось спрямованість і ступінь обдарованості різні. Подальша доля дару залежить від мікро- , мезо- й макросередовища, де живе й формується людина.

Щоб повніше зрозуміти змістове наповнення поняття «обдарованість», розглянемо сутність двох термінів: обдаровані діти та дитяча обдарованість. Дослідник О. Савенков терміном обдаровані діти позначає особливу групу дітей, «що випереджають однолітків у розвитку, а дитяча обдарованість, навпаки, не передбачає селекції, а кожна людина має певний інтелектуальнотворчий потенціал» [2]. Також науковець найбільш повно описав особливості обдарованої дитини: допитливість; відмінна пам'ять; гнучкість; надситуативна активність; здібність до прогнозування; продуктивність і оригінальність мислення; лідерство; високий рівень розвитку логічного мислення; підвищений інтерес до дивергентних задач; висока концентрація уваги; самостійність тощо [2].

Дефініція «обдарованість» визначається Д. Богоявленською як: системна якість психіки, яка визначає можливість досягнення людиною вищих результатів у одному або кількох видах діяльності порівняно 3 іншими людьми» [3]. Також автори зазначають, що поняття «обдарованість» і «творча обдарованість» виступають як синоніми [3], а дефініцію обдарована дитина визначають як «дитину, яка виділяється яскравими, очевидними, іноді визначними досягненнями (чи має внутрішні передумови для таких досягнень) в тому або іншому виді діяльності» [3].

Краще зрозуміти сутність поняття «обдарованість» допомагає визначення, подане сучасними дослідниками К. Крутій, О. Фунтіковою: «1. Загальні задатки та здібності, що зумовлюють діапазон можливостей людини, рівень та особливості іiі діяльності. 2. Якісне поєднання здібностей, що забезпечують успішність виконання діяльності та значні успіхи порівняно з іншими людьми. До компонентів обдарованості дошкільників можна віднести: домінантну роль пізнавальної мотивації, дослідницьку активність, можливість знаходити оригінальні рішення, можливість прогнозування тощо. Загальною ознакою обдарованості дитини $є$ випереджальний розвиток інтелекту щодо іiі віку» $[4$, с. 173].

Науковець В. Моляко трактує «обдарованість» як «міру генетично та досвідно зумовлених можливостей людини адаптуватися до життя, а здібності, як різні грані обдарованості, а не автономні складові». У дослідженнях дитячої творчості В. Молятко визначає психологічну структуру творчого потенціалу, яка збігається 3 такими структурними елементами, як «творчість», «творча особистість», «обдарованість» [5].

Дитячу обдарованість, характеризують також, як специфіку розвитку здібностей з урахуванням вікових особливостей дітей та прискорення розвитку інтелекту дитини. Проте, на думку науковців, коефіцієнт інтелекту (IQ) за результатами тестів не варто розглядати за єдиний критерій оцінки рівня 
дитячої обдарованості, особливо дошкільного віку (Д. Богоявленська [3], О. Савенков [2] та ін.). Адже, багаточисельні тести виміру інтелекту (IQ), виявляючи швидкість і точність знаходження вірного вирішення 3 безлічі можливих, не годяться для виміру креативності.

В процесі діагностики креативність підрозділяють на вербальну (словесне творче мислення) і невербальну (образотворче творче мислення). Таке розділення стало виправданим після виявлення зв'язку вказаних видів креативності з відповідними чинниками інтелекту: образним і вербальним.

Важливим у контексті нашого дослідження $\epsilon$ розуміння категорій «інтелектуальна обдарованість» i «творча обдарованість». Ці категорії виражають передумови та умови розвитку одна одної. Початок розмежуванню цих понять поклав Дж. Гілфорд. Оцінка «інтелекту» почала доповнюватися оцінкою «креативності», а також мотиваційних характеристик. Оскільки відмінність між інтелектом і творчістю відносна, то їх не варто протиставляти. Проте дослідник зазначав, що немає креативних осіб із низьким інтелектом, але $\epsilon$ інтелектуали з низькою креативністю [6].

Науковець М. Лейтес визначає поняття «потенційна обдарованість», яке використовується до дітей, які ще не проявили наявних обдарувань, однак володіють ними. Він запропонував виокремити «три групи дітей: із надзвичайно високим рівнем інтелекту; із звичайним рівнем розвитку інтелекту та помітними спеціальними здібностями; потенційно обдаровані (нереалізовані, непомічені, хоча володіють самобутністю мислення та спостережливістю тощо)» [1].

Варто зауважити, що дошкільний вік є найбільш сенситивним періодом, порівняно 3 усіма періодами життя, - для цілісного, гармонійного, особистісного, творчого розвитку дитини. Саме цей вік $є$ психологічною основою для творчої діяльності: розвиваються уява і фантазія, творче мислення, виховується допитливість, активність, ініціатива, формуються вміння спостерігати й аналізувати явища, проводити порівняння, узагальнювати факти, робити висновки, практично оцінювати діяльність. Починають складатися i диференціюватися інтереси, схильності, формуються потреби, що лежать в основі творчості. Розвиток творчого мислення невіддільний від формування виконавських умінь і навичок. Чим різнобічніші й досконаліші вміння та навички у дитини, тим багатші ії фантазія і реальніші задуми.

Відтак, особливе значення творча діяльність має для обдарованих i талановитих дітей, а важливими умовами розвитку творчих здібностей дітей дошкільного віку $\epsilon$ створення розвивального середовища в закладах дошкільної освіти (далі ЗДО), що випереджає розвиток дітей, спрямованість освітньої роботи на розвиток творчої особистості свобода у виборі та способі діяльності, психологічний комфорт у групі однолітків у ЗДО, реалізація індивідуального та диференційованого підходу до кожної особистості та розвиток ії найкращих здібностей та обдарувань тощо. 
Основними показниками творчих здібностей є: свобода (стрімкість, легкість думки) - кількість ідей за певну одиницю часу; гнучкість думки здатність швидко та без внутрішніх зусиль переключатися з однієї ідеї на іншу; оригінальність - здатність породжувати ідеї, що відрізняються від звичних, незвичайні рішення; допитливість - здатність дивуватися, цікавитись, відкритість до всього нового; точність - здатність удосконалювати свій творчий продукт, надавати йому завершеного вигляду; сміливість - здатність приймати рішення у ситуації невизначеності, не лякатися власних висновків, при цьому завершувати розпочату справу, ризикуючи особистим успіхом та репутацією [3].

Спираючись на дослідження вчених $[1 ; 2 ; 3 ; 5 ; 6]$ можна стверджувати, що виявити, розвивати та підтримувати дитячу обдарованість можна лише в процесі навчання і виховання, під час певної діяльності, де дитина може виявити самостійність, ініціативність, оригінальність виконання завдань, відкриття новизни та здатність до експериментування.

Для виявлення творчих здібностей, обдарованості та творчих можливостей розроблено різні методики, проте вони не можуть передбачити поведінку людини в реальних життєвих ситуаціях, в яких можуть проявитися оригінальні рішення. Виявлення творчої особистості проявляється, насамперед, у творчостій діяльності дітей, результатом якої є створення нових матеріальних і духовних цінностей для задоволення особистих і суспільних потреб. Психолого-педагогічні дослідження, що вивчають проблематику творчої особистості виділяють творчий потенціал як один із рушійних компонентів сучасної людини. Відзначається, що центральним поняттям у визначенні та розвитку обдарованих дітей стає поняття творчого потенціалу (А. Матюшкін [6], О. Моляко [5] та ін.), а творчість особистості поєднується із такими поняттями, як творча особистість, творчі здібності, творчий потенціал, творча діяльність тощо.

Дефініцію «творчість» найчастіше визначають як діяльність, результатом якої є створення якісно нових матеріальних і духовних цінностей. Водночас творчість являє собою здатність людини створювати 3 наявного матеріалу дійсності на основі пізнання закономірностей об'єктивного світу нову реальність [7]; як «продуктивну діяльність людини, яка здатна породжувати якісно нові матеріальні й духовні цінності суспільного значення» [4, с. 260].

Оскільки дошкільний період співпадає 3 першою фазою розвитку творчості, з «первинною креативністю», то внутрішньою передумовою творчої діяльності $\epsilon$ творчий потенціал як «ресурс творчих можливостей людини, здатність до здійснення творчих дій та діяльності» [4, с. 14]. Тобто, максимальне виявлення творчого потенціалу виникає в тих ситуаціях, коли дитина намагається використати нетиповий для себе засіб, метод вирішення проблеми.

Відтак, у концепції А. Маслоу проявом вищого рівня потреб людини є самоактуалізація, тобто повне застосування талантів, здібностей, потенціалів 
тощо. «Самоактуалізація - це процес, коли здібності індивіда розкриваються повністю, творчо і радісно. Потреба самоактуалізації виявляється в різних формах: у кожного - свої мотивація, здітності, спрямованість. Креативність, щирість, сміливість, наполеглива праця - основні характерні риси самоактуалізованих людей» [7, с. 4].

Творчий потенціал інтелектуально обдарованої дитини характеризує його особистість в цілому i являє собою систему когнітивних i некогнітівних компонентів, представлених інтелектуальними (оригінальність, гнучкість, адаптивність, швидкість й оперативність мислення; легкість асоціацій; рівень творчої уяви), і особистісними (мотиваційними, емоційними, вольовими, рефлексивними та ціннісно-смисловими) характеристиками у їх взаємодії.

Здатність дитини до творчості проявляється в процесі їі життєдіяльності, при цьому будь-який з видів діяльності може здійснюватися індивідом, як на репродуктивному, так і на творчому рівні. При цьому практично не береться значення творчих здібностей дитини, які можна розглядати як одну 3 умов розвитку особистості та прояви адаптаційних можливостей.

Показники креативності виділяються як за кількістю кореляційних зв'язків 3 показниками інших психічних утворень, так і за місцем в структурі цих зв язків. Вони пов язані 3 показниками, що відображають особливості сенсомоторної i афективної сфер, інтелекту, темпераменту i мотивації. Складність взаємозв 'язків між різними за своєю природою психічними проявами можна вважати характерною для даного віку, вона відображає структурні особливості розвитку дошкільників.

Категорії «обдарованість» та «творча обдарованість» взаємопов'язані у працях науковців В. Моляко та О. Музики, які визначають поняття «обдарованість» як «творчу обдарованість, а «обдаровану особистість», як творчо обдаровану особистість» [5]. Тобто, що ці поняття виступають як синоніми.

Розглядає творчу обдарованість «як загальну психологічну передумову творчого розвитку й становлення творчої особистості» - науковець

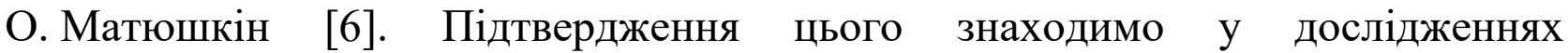
П. Каптерьова, який вважає, що «сутність творчого потенціалу полягає, передусім, у творчій діяльності» [10].

Сам термін «творчий потенціал» використовується не настільки часто, як креативність. Крім того, креативність визначається як загальна творча здатність і творчий потенціал, як системна характеристика особистості; як «рівень творчої обдарованості, здатності до творчості, що становить відносно стійку характеристику особистості. Раніше креативність розглядалася як функція інтелекту, i рівень розвитку інтелекту ототожнювався 3 рівнем розвитку креативності. Пізніше з'ясувалося, що рівень інтелекту корелює із креативністю до певної межі, а досить високий інтелект чинить перепони розвитку креативності» [4, с. 126]; як «інтегративну властивість особистості, 
що характеризує міру можливостей дитини здійснювати творчу діяльність, визначає потребу, готовність і здатність до творчої самореалізації, а також забезпечує ефективну взаємодію особистості 3 іншими людьми та високу продуктивність діяльності» [28]; як синтетичну якість, що характеризує міру можливостей дитини ставити й розв'язувати нові завдання у різних формах життєдіяльності» [3]; як здібність до творчості, «ресурс творчих можливостей людини, здатність конкретної людини до здійснення творчих дій, творчої діяльності» [5, с. 120]; як «внутрішнє джерело творчості, що є взаємодією якостей і властивостей особистості, здатних реалізуватися у конкретному творчому акті [8]; «сукупність можливостей та здібностей особистості, необхідних для творчої діяльності» [4, с. 200].

А ось креативність дитини дошкільного віку науковці трактують як «одну iз базисних характеристик особистості дитини дошкільного віку, що характеризує активну позицію дитини, готовність до спонтанних рішень, допитливість, здатність до мовленнєвого коментування процесу та результату своєї діяльності, стійку мотивацію досягнень, розвинуту уяву, а також здатність до створення творчого образу, який є оригінальним, варіативним та рухливим» [4, с. 126]. Визначають різні види креативності: «первинну» (загальну) - загальна здібність до творчості, яка розвивається у дітей 6-7 років під впливом сприятливих факторів середовища; потенційну - вроджені передумови креативності; спеціалізовану (актуальну) - здібність до творчості у певній сфері діяльності (у літературній, музичній, науковій творчості тощо), розвивається на основі загальної креативності під впливом досвіду діяльності [4, с. 11].

Цінним для нашого дослідження є визначення дефініції «креативність» науковцями К. Крутій, О. Фунтікою, які розглядають іï як «рівень творчої обдарованості, здатності до творчості, що становить відносно стійку характеристику особистості. Раніше креативність розглядалася як функція інтелекту, i рівень розвитку інтелекту ототожнювався 3 рівнем розвитку креативності. Пізніше з'ясувалося, що рівень інтелекту корелює із креативністю до певної межі, а досить високий інтелект чинить перепони розвитку креативності» [4, с. 126].

Звернімося до трактування поняття «творчий потенціал»: «здатність індивіда сконцентруватися на об'єкті сприймання, від чого залежить сила, 3 якою окремі його властивості діють на органи відчуття, та ефективність активізації тимчасових нервових зв'язків» [8]; «сукупність можливостей та здібностей особистості, необхідних для творчої діяльності» [4, с. 200].

Щодо структури творчого потенціалу грунтовними для нас $\epsilon$ підходи Є. Ільїна, відповідно до яких «творчий потенціал людини розглядається у вузькому та широкому сенсах. У вузькому сенсі це творчі здібності, здатність до творчого потенціалу та дивергентного мислення, в широкому - це ще й властивості особистості, що сприяють реалізації творчих здібностей, а саме: 
мотиви, деякі емоційні та вольові якості, рівень компетентності» [7]. Науковець вважає, що для розвитку дивергентності мислення необхідні дивергентні задачі, які передбачали б декілька варіантів і способів вирішення» [7]. Також серед матеріалів досліджень, присвячених структурі та змісту творчого потенціалу особистості, помітно спрямовані на потребу унікальності, мотивацію творчої активності й ціннісні орієнтації.

До складників творчого потенціалу включають: спеціальні структури мотиваційної, емоційної та вольової сфер, вищі рівні когнітивних процесів, особливості самосвідомості особистості. У цілому, питання про структуру творчого потенціалу особистості до кінця не вирішене.

Водночас, системний та особистісний підхід до обдарованості висувають поняття творчого потенціалу на перший план у якості найбільш продуктивного при вирішенні проблем розвитку творчої особистості дитини (О. Матюшкін [6], А. Лукановська [10] та ін).

Як зазначає А. Лукановська, «потенціал - це величина, що характеризує потенційну енергію суб’єкта творчості. Творчий потенціал у філософському плані розглядається як синтетична якість індивіда, що характеризує міру іï можливостей ставити й вирішувати нові завдання у сфері діяльності, яка має суспільне значення. Його можна представити у вигляді сукупності перетворювально-предметних, пізнавальних, аксіологічних, комунікативних, художніх можливостей» [10].

Підтвердження цього знаходимо у дослідженнях В. Маслової - «творчий потенціал обдарованої дошкільника характеризує його особистість у цілому i включає в себе систему мотиваційних, емоційних, інтелектуальних і вольових характеристик особистості» [11].

Дослідник О. Матюшкін пов'язує обдарованість 3 високим рівнем творчого потенціалу, який проявляється, «у високій дослідницькій активності. Відповідно цього підходу ранні та високі прояви ознак обдарованості особистості складають передумову наступного творчого навчання та розвитку. Зовнішні прояви творчого розвитку виражаються через допитливість дитини, iіi дослідницьку активність, пришвидшений розвиток мови та мислення, ранню захопленість музикою, малюванням, конструюванням, рахунком» [6].

Узагальнення теоретичних напрацювань і практичного досвіду науковців (С. Кульчицької [12], Т. Піроженко [13] та ін.) дозволило виокремити складники творчого потенціалу дошкільника, як сукупності можливостей, потенціалів, а саме: перетворювально-предметного; аксіологічного та саморозвитку. Варто відзначити, що творчий потенціал особистості у вузькому сенсі підлягає діагностуванню, у широкому - тільки прогнозується 3 урахуванням ступеня розвитку особистісних якостей.

Порівнюючи вище зазначені дослідження творчого потенціалу особистості, можна зробити висновок, що творчий потенціал визначається основними формами прояву психіки людини, а саме: пізнавальними та 
емоційно-вольовими процесами, психічними станами, якостями, спостережливістю, творчою уявою, мимовільною пам'яттю; мисленням, а також особистісними якостями: самостійністю, сміливістю, допитливістю, креативністю, а найбільше проявляється у ігровій, конструкторській, образотворчій та мовленнєвій діяльності дитини в єдності своїх сторін: духовної, інтелектуальної та трудової.

У ЗДО використовуються різноманітні методики дослідження творчого потенціалу: методика Торренса «16 кружечків», методика «Домалюй фігуру» (версія О. Дяченка), «Діагностика творчої уяви» (за Г. Войтович), методика завершення речень (Л. Дерев'янко) для визначення творчих здібностей дошкільнят; методики завершення речень (Л. Дерев’янко) для визначення творчих здібностей дошкільнят («Для мене найцікавіше...», «Мені подобається...» та ін.); методики «Творча оригінальність» (за А. Симановським) застосовується для визначення рівня оригінальності мальованих образів (10 аркушів). Дітям пропонується уявити себе чарівником i перетворити фігурку у будь-яку красиву картинку; методика А. Біне-Т. Сімона - вивчення розумового розвитку, варіант Л. Термена для визначення рівня сформованості інтелектуально-творчого потенціалу (здатність переключати увагу, швидко переходити з вирішення одних задач на виконання інших, не допускаючи при цьому помилок) та ін. [14].

Для розвитку творчих здібностей у роботі 3 дітьми використовуються вправи та ігри на кшталт: «Ланцюжок слів», «Політ фантазії», «Довільний префікс», «Творча помилка», «Фантастичні гіпотези», «Оживлення навколишніх предметів», «Конструювання загадок», «Різнобарвні крижинки», «Опиши предмет», «Головоломки», «Збери за схемою», «Зашифруй казку», «Знайди всі доріжки», «Дослідники», «Знайди відрізані шматочки», «Чомучки», «Винахідники», «Золоті руки», «Склади речення», «Чарівні кола», «Придумай історію», «Плями», «Мандрівка у хмарах» тощо.

3 метою розвитку творчого потенціалу в обдарованих дітей дошкільного віку робота з дітьми здійснюється у таких напрямках: відбір змісту програмних завдань, що стимулюють розвиток творчого потенціалу дітей; розробка системи занять; вправ, дидактичних ігор; створення розвивального, творчого середовища в групах ЗДО; участь дітей у різноманітних видах дитячої діяльності (зображувальна, конструктивна, ігрова, художньо-мовленнєва, театралізована тощо); забезпечення суб'єкт-суб’єктної взаємодії вихователя і дітей у ході організації спільної творчої діяльності; спільна робота ЗДО із сім'єю.

Для розвитку творчих здібностей дошкільників використовуються методи активізації пошуку: метод фокальних об'єктів, мозковий штурм, синектика; усний лабіринт; асоціацій; пошуку причин і наслідків подій; створення дитиною власних дослідницьких проектів, ТРВ3 (теорія розв'язання винахідницьких завдань тощо. Саме такі методи докорінно змінюють стиль 
роботи вихователя 3 дітьми, робить їх вільними, вчать думати, шукати, розв’язувати свої проблеми самостійно, а головне, - допомагають дорослим життєрадісно та винахідливо збуджувати інтерес дітей до творчості, виховують душу, здатну робити добрі і прекрасні вчинки.

Дослідник Г. Альтштулер виділив основні принципи, які лежать у основі TPВ3: принцип об'єктивності законів розвитку систем; принцип суперечності; принцип конкретності; принцип свободи вибору; принцип відкритості; принцип діяльності; принцип зворотного зв'язку; принцип ідеальності тощо [15]. Науковець акцентує увагу на тому, що «Кожній людині має бути доступна творчість найвищого рівня. Творчий людині жити нелегко, але натомість вона здатна пізнавати радість відкриття й знаходити собі застосування в різних сферах діяльності. Із всіх відомих методів пошуку рішень ТРВ3 залишилася жити й продовжує успішно розвиватися. ТРВ3 - це методологія пошуку нових розв’язань, що дає стабільні позитивні результати і не впливає шкідливо на психіку людини» [15, 321].

Усі методи та форми діяльності використовуються як самостійні (коли проводиться індивідуальна робота), робота в малих групах (у вигляді індивідуальних завдань під час гурткової роботи), так і під час проведення занять (комплексних, комбінованих, нетрадиційних, інтегрованих), i в повсякденному житті дітей (під час прогулянок, екскурсій), проводяться i фронтально - 3 усіма дітьми групи. Використання різноманітних форм i методів роботи 3 дітьми передбачає актуалізації емоційно-вольової і пізнавальної активності дитини у процесі розв'язання творчих завдань; розвиток критичного й логічного мислення, виконавчої майстерності, розвиток творчого художнього мовлення тощо. Проте слід пам'ятати, що реалізація творчого потенціалу дитини без позитивного ставлення до себе - неможлива. Тому необхідно піклуватися про створення психологічного комфорту, безпеки 3 боку дорослих щоб дитина була впевнена у позитивній оцінці власної діяльності, не боялася ризикувати, створюючи щось нове і неординарне.

Висновки. Отже, ні пришвидшення, ні збагачення навчальної програми не можуть розв'язати всього комплексу проблем виявлення та розвитку творчого потенціалу обдарованих дітей. Вважаємо, цю проблему можна розв'язати тільки впровадженням розвивальних програм, які відкривають можливості для розвитку творчого потенціалу обдарованих дітей та створенням розвиваючого середовища в ЗДО та сім’ї. Відтак, педагогічну освітню діяльність з розвитку творчого потенціалу в обдарованих дітей умовах сучасного освітнього простору ЗДО розглядаємо як комплексну технологію, систему професійної діяльності, спрямовану на створення умов для творчого розвитку обдарованості дитини дошкільного віку у формуванні їі творчої унікальності. Перспективу подальших наукових пошуків вбачаємо у дослідженні особливостей забезпечення та підтримки обдарованих дітей у сучасному освітньому просторі ЗДО. 


\section{Лimepamypa:}

1. Лейтес Н. С. Ранние проявления одаренности. Вопросы психологии. 1988. № 4. С. $98-107$.

2. Савенков А. И. Одаренные дети в детском саду и школе: Учеб. пособие для студ. высш. пед. учеб. заведений. Москва: Академия, 2000. 232 с.

3. Рабочая концепция одаренности / [Д. Б. Богоявленская, А. В. Брушлинский, В. Н. Дружинин и др.]; науч. ред. В. Д. Шадриков. Москва: «Магистр», 1998. 68 с.

4. Дошкільна освіта: словник-довідник: понад 1000 термінів, понять та назв / упор. К. Л. Крутій, О. О. Фунтікова. Запоріжжя: ТОВ «ЛІПС» ЛТД, 2010. 324 с.

5. Здібності, творчість, обдарованість: теорія, методика, результати досліджень / [за ред. В. О. Моляко, О. Л. Музики]. Житомир: Вид-во Рута, 2006. 320 с.

6. Матюшкин А. М. Концепция творческой одаренности. Вопросы психологии. 1989. № 6. С. 29-33.

7. Ильин Е. П. Психология творчества, креативности, одаренности. СПб.: Питер, 2009. $448 \mathrm{c}$.

8. Обдаровані діти: Діагностика та супровід / [упоряд. Т. Червонна]. Київ: Шкільний світ, 2008. 128 с.

9. Каптерев П.Ф. О природе детей: Статьи, советы и рекомендации. Москва: Карапуз, 2005. 284 с.

10. Лукановська А. В. Творчий потенціал особистості: структурні компоненти URL: http://journals.uran.ua/index.php/2227-6246/article/view/162126 (дата звернення: 30.12.2021).

11. Маслова В.И. Психологические условия развития творческого потенциала одаренных детей дошкольного возраста: автореферат дис. ... кандидата психол. наук. Нижний Новгород, 2003. 24 с.

12. Кульчицька О. І. Проблеми обдарованості в сучасній психології. Обдарована дитина. 2008. № 1. С. 2-7.

13. Піроженко Т. О. Проблема реалізації індивідуального підходу до розвитку дитини в умовах дошкільного віку. Спеціалізований журнал «Практичний психолог: дитячий садок». 2013. № 10. С. 4-12.

14. Проценко О. В. Розвиток здібностей та обдарувань у дошкільників. Київ: Шк. Світ, 2011. $128 \mathrm{c}$.

15. Альтштулер Г.С. Как стать гением: Жизненная стратегия творческой личности. Минск, 1994. 497 с.

\section{References:}

1. Leytes N. S. (1988). Rannie proyavleniya odarennosti. [Early manifestations of giftedness]. Voprosyi psihologii-Psychology issues.4. 98-107. [in Russian].

2. Savenkov A. I. (2000). Odarennyie deti v detskom sadu i shkole: Ucheb. posobie dlya stud. vyissh. ped. ucheb. zavedeniy. [Gifted children in kindergarten and school: a textbook for students of higher pedagogical educational institutions]. Moskva: Akademia [in Russian].

3. Rabochaya kontseptsiia odarennosti (1998) [Working concept of giftedness] / [D. B. Bogoyavlenskaya, A. V. Brushlinskiy, V. N. Druzhinin i dr.]; nauch. red. V. D. Shadrikov. Moskva: Magistr [in Russian].

4. Doshkilna osvita: slovnik-dovIdnik: ponad 1000 termInIv, ponyat ta nazv [Preschool education: vocabulary-guide: 1000 terms, understand the name], / upor. K. L. Krutiy, \& O. O. Funtlkova. Zaporizhzhia (2010): TOV «LIPS» LTD [in Ukrainian].

5. Zdsbnosti, tvorchist, obdarovanist: teoriia, metodyka, rezultati dosiIdzhen. (2006). [Abilities, creativity, talent: theory, methodology, research results] / [za red. V. O. Molyako, O. L. Muziki]. Zhitomyr: Vyd-vo Ruta [in Ukrainian]. 
6. Matyushkin A. M. (1989). Kontseptsiia tvorcheskoy odarennosti [Creative giftedness concept] Voprosyi psihologii - Psychology issues. 6. 29-33 [in Russian].

7. Ilin E. P. (2009). Psihologiia tvorchestva, kreativnosti, odarennosti. [Psihologiya tvorchestva, kreativnosti, odarennosti]. SPb.: Piter, [in Russian].

8. Obdarovani dity: Diagnostyka ta suprovid (2008). [Gifted children: Diagnosis and support] / [uporiad. T. Chervonna] Kyiv: Shkilniyi svit [in Ukrainian].

9. Kapterev P. F. (2005) O prirode detey: Stati, sovetyi i rekomendatsii. [On the nature of children: Articles, tips and advice]. Moskva: Karapuz [in Russian].

10. Lukanovska A. V. (2010) Tvorchiy potentsial osobistosti: strukturni komponenty. [Creative potential of the individual: structural components.]. Zbirnyk naukovyh prats «Problemy suchasnoi psihologii» - Collection of scientific works «Problems of modern psychology». Retrieved from: http://journals.uran.ua/index.php/2227-6246/article/view/162126 [in Ukrainian].

11. Maslova V. I. (2003). Psihologicheskie usloviia razvitiia tvorcheskogo potentsiala odarennyih detey doshkolnogo vozrasta. [Psychological conditions for the development of the creative potential of gifted preschool children]. Extended abstract of candidate's thesis. Nizhniy Novgorod [in Russian].

12. Kulchitska O. I. (2008). Problemi obdarovanosti v suchasniy psihologii. [Problems of giftedness in modern psychology]. Obdarovana dytyna - A gifted child. 1, 2-7 [in Ukrainian].

13. Pirozhenko T. O. (2013). Problema realizatsii individualnogo pidhodu do rozvitku dytyny v umovah doshkilnogo viku. SpetsIalIzovaniy zhurnal «Praktichniy psiholog: dityachiy sadok»-Specialized magazine «Practical psychologist: kindergarten». 10. 4-12. [in Ukrainian].

14. Protsenko O. V. (2011) Rozvytok zdibnosteyi ta obdaruvan u doshkilnykiv [Development of abilities and talents in preschoolers]. Kyiv: Shkilniyi Svit [in Ukrainian].

15. Altshtuler G.S. (1994). Kak stat geniem: Zhiznennaya strategiya tvorcheskoy lichnosti. [How to Become a Genius: The Life Strategy of a Creative Person], Minsk [in Belarus]. 